the provision of early-warning mechanisms and the establishment and enforcement of local preventive measures along with community education, preparedness, response, and rehabilitation'.

Statistics clearly show that, even in less-developed countries, adherence to these measures leads to a reduction of damage and loss of lives. Using as an example Hurricane David, which struck Dominica in 1979, Professor Obasi recalled the long-lasting impact that the disaster had on the island's economy, which had suffered a severe setback and a decline of $78 \%$ to $84 \%$ in GDP per caput during the ten years' period after the disaster.

WMO is involved in the activities of the current International Decade for Natural Disasters Reduction (IDNDR), which is now at its mid-decade point. 'I would hope that this Conference will bring to light the unique needs and requirements for sustainable development that can go hand in hand with the efforts which are being deployed in the context of the IDNDR towards the reduction of natural disasters globally', said the WMO Secretary-General, before outlining the following seven specific actions that could be taken by countries and the international community:

- Undertake an internationally-coordinated comprehensive risk-assessment programme to provide a standard baseline for disaster reduction;

- Strengthen the acquisition of meteorological and hydrological data, telecommunications, and data-processing infrastructures, using regionally coordinated mechanisms such as the WMO World Weather Watch and Tropical Cyclone Programmes;

- Initiate the development of prediction capabilities of other geophysical phenomena such as volcanoes and earthquakes;

- Invest in specific programmes for preparedness, including the development or improvement of hazardspecific building codes and land-use practices, public education, and warning systems;

- Participate in international programmes such as the World Climate Programme, so that specific concerns of Small Island Developing States are placed high on the priority list of studies to determine the impact of climate, its variation and change, and potential sea-level rise;

- Organize and promote specific regional technical cooperation programmes designed to assist Small Island Developing States to reduce the impacts of tropical cyclones, floods, volcanoes, earthquakes, tsunamis, and climate change including sea-level rise; and

- Develop effective public-information services, based on scientifically sound studies and analyses, in order to lead to concerted international action to promote sustainable development.

InFormation AND Public AfFairs OfFice World Meteorological Organization PO Box 2300

CH-1211 Geneva 2 Switzerland.

\title{
The Significance of Urban Nature
}

$\mathrm{F}^{\mathrm{r}}$ rom time to time and particularly in recent years, articles have appeared in Environmental Conservation concerning the urban environment and its resident biota, whether on urban environmental institutions (Adams, 1989); specific biota (e.g. Proulx, 1988, Fitzgerald, 1990, Jarvis, 1990, on cats; Fossi \& Renzoni, 1989, Guthová, 1993, on seagulls); urban habitat management and monitoring (Zhou et al., 1989); or the effects of urban systems on global ecology and Humankind (Ress, 1989; Shaw, 1989).

These papers and notes have conformed to the (helpfully broad) definitions of urban ecosystems proposed in 1984 by H. Sukopp, who has emphasized the social and historical aspect of increasing urbanization. Meanwhile, numerous commentators have stressed the need for integrating knowledge across the broad spectrum of disciplines involved in the urban environment, in order that true and effective environmental management can be carried out.

At the same time, various influential international bodies have published policy papers on the urban environment - including the European Commission (in 1990), the Organization for Economic Cooperation and Development (in 1990), and, most recently, the United Nations' Local Agenda 21 (see Levett, 1993). Most pertinently, Levett emphasizes (Chapter 35: Science for Sustainable Development) that 'Scientific knowledge should be applied to articulate and support the goals of sustainable development, through scientific assessments of the current conditions and future prospects for the Earth system.'
We are now at a stage where people are agreed that action is necessary to manage the urban environment, but where there are few areas of concensus on any individual issue - quite likely because of lack of scientific knowledge.

This is where (we hope) our Urban Nature Magazine comes in, for it is planned continuingly to offer a quarterly review of the latest findings regarding all manner of biota occurring in and around towns and cities. It offers commentaries (some of them controversial) and scientific papers on a variety of topics - ranging from valuing Nature in cities, to the classification of urban aquatic communities, and the importance of the urban ecocomplex overall. We would now like, through the kind hospitality of Environmental Conservation, to invite your contributions and subscriptions to Urban Nature in this, its third year of production *.

\section{REFERENCES}

ADAMS, L.W. (1989). National Institute for Urban Wildlife. Environmental Conservation, 16(3), pp. 276-7.

FitzGERALD, B.M. (1990). Is cat control needed to protect urban wildlife? Environmental Conservation, 17(2), pp. 168-9.

*We heartily support this plea, believing that such a Journal well edited and concerned also with surrounding areas from and to which plants and animals migrate - is becoming more and more needed as urbanization increases - see our book in press on Population and Global Security. As for ourselves, we have always considered urban topics as somewhat marginal for Environmental Conservation as formerly for Biological Conservation, and tend to have too much good material coming in anyway. - Ed. 
Fossi, C. \& Renzoni, A. (1989). Metabolic adaptations of certain seagulls to our changing world. Environmental Conservation, 16(4), pp. 356-7.

JARVIS, P.J. (1990). Urban cats as pests and pets. Environmental Conservation, 17(2), pp. 169-71.

GUTHOVÁ, ZUZANA (1993). Variations in reproduction parameters of Black-headed Gulls (Larus ridibundus) living in different conditions in the Czech and Slovak Republics. Environmental Conservation, 20(4), pp. 347-51 (5 figs and 3 tables).

LEVETT, R. (1993). Earth Summit--Rio '92. Supplement $\mathrm{Nr} 2$. (Agenda 21: A Guide For Local Authorities in The UK.) Local Government Management Board, Luton, England, UK: [not available for checking].

Proulx, G. (1988). Control of urban wildlife predation by cats through public education. Environmental Conservation, 15(4), pp. 358-9 (4 figs).

REss, P.E. (1989). Cities in distress: WHO sounds the alarm. Environmental Conservation, 16(4), pp. 366-7 (fig.).
SHAW, R.P. (1989). Rapid population growth and environmental degradation: ultimate versus proximate factors. Environmental Conservation, 16(3), pp. 199-208 (3 figs and table).

ZHoU, M.M., YI, L.J., BERTINE, K.K., KoIDE, M. \& GoldBERG, E.D. (1989). Atmospheric pollution in Beijing, China, as recorded in sediments of the Summer Palace Lake. Environmental Conservation, 16(3), pp. 233-6 (fig. and 5 tables).

GERALD F.M. DAWE, Editor

KEITH GRICE, Managing Editor

Urban Nature Magazine

Urban Environment

40 Milford Road

Birmingham B17 9RL

England, UK.

\section{IIASA Goes Global}

$\mathrm{T}^{\mathrm{s}}$ he International Institute for Applied Systems Analysis (IIASA, of Laxenburg, Austria) is an interdisciplinary, nongovernmental research institution that is sponsored by a consortium of National Member Organizations in 17 nations. The Institute conducts international and interdisciplinary scientific studies to provide timely and relevant information and options, addressing critical issues of global environmental, economic, and social, changes, for the benefit of the public, the scientific community, and national and international institutions. Its research programme focuses on three central themes: Global Environmental Change; Global Economic and Technological Transitions; and Systems Methods for the Analysis of Global Issues.

The establishment of a new North-South Fund has been announced by Dr Peter E. de Jánosi, Director of IIASA. The Fund is intended to increase the involvement of scientists from the developing world in the research work carried out at IIASA. Although founded as an EastWest Institute, IIASA has, since its inception in 1972, also worked on international and global problems; indeed, with the end of the Cold War, the Institute's agenda has focused on problems of global change. This fact was recognized in the awarding of a two-years' grant by the Rockefeller Foundation of New York, beginning in May 1994. This grant provides the seed money for IIASA's North-South Fund, which is expected to be supplemented from other sources.
The Institute's current agenda calls for the study of human, environmental, and economic, dimensions of global change. This includes the less-industrialized countries of the Southern hemisphere, many of which are striving to meet development goals in the face of mounting urban pressures, population growth, rapid social change, and widespread environmental constraints.

'There is a clear need for the perspective and inputs of researchers from the South in the study of solutions to the global problems that IIASA now addresses', says Dr de Jánosi. "Most of the projects at the Institute already have excellent connections world-wide, so we expect no difficulty in locating and recruiting the talent that is available', he adds. The establishment of the North-South Fund, which effectively begins with this grant from the Rockefeller Foundation, will ensure financial support for selected scholars from developing countries to work at IIASA. The inclusion of a North-South view will expand IIASA's horizons without detracting from its traditional East-West connections and perspectives.

\section{ELISABETH KRIPPL, Head Public Information IIASA}

A-2361 Laxenburg

Austria.

\section{The Almería Statement on Desertification and Migration *}

$\mathrm{W}$ e must protect the land that feeds us. Following upon the United Nations Conference on Environment and Development, held in Rio de Janeiro in June 1992, and based on recommendations contained in Agenda 21, particularly its Chapter 12 on 'Managing fragile ecosystems: combating desertification and drought', the General Assembly of the United Nations decided to establish an Intergovernmental Negotiating Committee for the Elaboration of an International Convention to

* Emanating from the International Symposium on Desertification and Migration, held in Almería, Spain, during 9-11 February 1994, as reported on pages $85-6$ of our preceding issue by Dr Arthur H. Westing who communicated this statement. - Ed.
Combat Desertification in those countries experiencing serious drought and/or desertification, particularly in Africa [Res. 47/188, 22 Dec. '92].

Desertification is a global phenomenon, affecting all continents, engendering cross-boundary and transcontinental migrations, and forcing people in vulnerable areas [that have been] marginalized by poverty and ecological degradation, to look for better living opportunities in cities, other regions, or other countries, where further strains on the natural and social environments are apt to occur.

We must face the issues confronting the people who inhabit affected arid lands. The General Assembly of the United Nations called for an International Conference on 